\title{
Feasibility and psychometric analysis of graduate satisfaction survey of medical students graduating from the Royal College of Surgeons in Ireland-Medical University of Bahrain (RCSI Bahrain)
}

\author{
Kathryn Strachan ${ }^{1}$ and Ahmed Al Ansari ${ }^{1,2,3^{*}}$
}

\begin{abstract}
To assess the satisfaction levels of graduates of the Royal College of Surgeons in Ireland University of Bahrain (RCSI Bahrain). The graduate survey was administered to four groups of graduates of the RCSI Bahrain who graduated between the years 2010 and 2014. The graduate survey assessed five major domains and comprised 41 items. The RCSI Bahrain opened its doors in 2004, with the first class graduating in 2010. The graduate cohorts used in this study were working in various countries at the time of survey completion. Out of 599 graduates, 153 responded to the graduate survey. The total mean response rate of the graduate survey was $26 \%$, including 102 females, 44 males, and 7 students who did not indicate their gender. 49 students graduated in 2012, and 53 students graduated in 2013. Of these graduates, 83 were working in Bahrain at the time of survey administration, 11 in the USA, 4 in Malta, and 3 in the UK; the total number of countries where graduates were working was 14. Reliability analysis found high internal consistency for the instrument (with a Cronbach's a of 0.97). The whole instrument was found to be suitable for factor analysis ( $K M O=0.853$; Bartlett test significant, $\mathrm{p}<0.00$ ). Factor analysis showed that the data on the questionnaire decomposed into five factors, which accounted for $72.3 \%$ of the total variance: future performance, career development, skills development, graduate as collaborator, and communication skills. The survey results found that graduates of the RCSI Bahrain program who responded to this questionnaire are generally satisfied with their experience at the university, feel well prepared to join the field and feel ready to compete with graduates of competing universities. Furthermore, the graduate survey was found to be a reliable instrument and we provided some evidence to support the construct validity of the instrument.
\end{abstract}

Keywords: Graduate survey, Validity, Reliability

\section{Background}

Upon graduation from medical school, it is important for universities to monitor student satisfaction, to build on constructive feedback and to further improve the quality of education offered. The Graduation Questionnaire was

\footnotetext{
*Correspondence: drahmedalansari@gmail.com; ahmed.alansari@bdfmedical.org

${ }^{2}$ Department of General Surgery, Bahrain Defense Force Hospital, Off Waly Alahed Avenue, P. O. Box - 28743, West Riffa, Kingdom of Bahrain Full list of author information is available at the end of the article
}

first established by the Association of American Medical Colleges (AAMC) in 1978, and medical schools receive the results of both their institution as well as other medical programs nationwide for comparison (Association of American Medical Colleges 2012). The Medical School Graduation Questionnaire administered by the AAMC produces an annual report that analyzes a variety of aspects of graduate experiences. The questionnaire covers medical education topics, clinical experiences,

\section{Springer}

C 2016 Strachan and Ansari. This article is distributed under the terms of the Creative Commons Attribution 4.0 International License (http://creativecommons.org/licenses/by/4.0/), which permits unrestricted use, distribution, and reproduction in any medium, provided you give appropriate credit to the original author(s) and the source, provide a link to the Creative Commons license, and indicate if changes were made. 
preparedness for residency, financing of education, and overall satisfaction, amongst others (Mavis et al. 2014).

Past research has established that more recent cohorts of medical school graduates tend to rate higher satisfaction than previous ones (Lambert et al. 2013). This is likely due to the notion that medical schools are continuously improving their respective programs based on feedback from their graduates. Previous studies have also indicated that new physicians often find difficulty in the areas of time management, paperwork, inpatient ward work and working on-calls; however these are areas that the authors argue are best learned through experience rather than the type of training learned in a scholarly setting (Illing et al. 2013). As such, this questionnaire is useful both as an evaluation method as well as a quality improvement process.

Such surveys are an important tool for developing medical education programs that are catered to the specific needs as seen from a student's perspective. These questionnaires may then be used to improve rates of graduate preparedness for practicing medicine at the residency level. Similar questionnaires have been used in a variety of countries to change the medical curriculum. For instance, a study conducted in Poland found that students who shadowed surgeons in the operating room, observing the procedures rather than participating in them, found this learning method to be inadequate to prepare them for performing surgery themselves (Lambert et al. 2013). As such, the curriculum evolved to include hands-on training using surgical simulators (Illing et al. 2013). The purpose of this study therefore was to assess the satisfaction and preparation levels of graduates of the RCSI Bahrain.

The RCSI Bahrain opened its doors in 2004, with the first class graduating in 2010. The RCSI was first established in Dublin, Ireland in 1784. Medical interns graduating from RCSI Bahrain have established a $100 \%$ pass rate for the Bahrain National Health Regulatory Authority licensing exams thus far. For the most part, staff and faculty are primarily from Bahrain and Ireland, respectively.

In 2013, the medical school was invited to join the Global Education in Medicine Exchange (GEMx) affiliated to the Educational Commission for Foreign Medical Graduate (ECFMG) and the Global Health Learning Opportunities Collaborative (GHLO), affiliated to the Association of American Medical Colleges (AAMC). Both initiatives provide a network of collaborating institutions around the world, facilitating global mobility for our medical students pursuing international clinical or research electives. In 2014 there were more than 1278 students from 36 different countries and a total of 138 fulltime staff.
The aim of this study therefore was to assess the satisfaction and self-reported preparation levels of graduates of the Royal College of Surgeons of Ireland University of Bahrain (RCSI Bahrain).

\section{Methods}

\section{Study settings and participants}

The study included all of the students who graduated from the RCSI-Bahrain in the Kingdom of Bahrain. The participants included 102 female and 44 male graduates, to a total of 146 participants. The RCSI Bahrain opened its doors in 2004, with the first class graduating in 2010. In 2014 there were more than 1278 students from 36 different countries.

The graduate survey was administered via email to a total of 599 students; these students comprise four cohorts of graduates of the RCSI Bahrain who graduated between the years of 2010-2014. The graduates used in this study were working in various countries at the time of survey completion. The first e-mail was sent to the graduates by December 2014. This was followed by another two e-mails within a three-week interval. Graduates were contacted through their RCSI e-mail that was assigned to them by the university during the study. The name of the graduates was not mandatory for completing the survey. Confidentiality of the participants was preserved.

\section{Instrument}

The graduate survey is a tool that was developed by an expert team from the RCSI in Dublin. Face and content validity was established by expert opinion and a table of specification. We addressed face and content validity by sending the instrument to an expert in the field to review the content and format of the instrument and judge whether or not it is appropriate. The questions of the survey were assessed against the table of specification, which was constructed by the authors.

The survey comprised of 41 items and assessed five major domains ranged on a 5-point likert scale. The items on the instrument had a 5-point response scale in the form of, $1=$ strongly disagree; $2=$ disagree; $3=$ neither agree nor Disagree; $4=$ agree; $5=$ strongly agree" with an option of "unable to assess" UA. After the committee had developed the questionnaire, they were sent to group of physicians whose work fit the profile for episodic care, for feedback. The questionnaire was modified following that feedback. The items in the questionnaire are presented in Table 1 .

\section{Statistical analysis}

Data analysis was conducted with SPSS version 20.0. Each research question underwent a number of statistical 
analyses. Feasibility of the questionnaire was analyzed via response rates and the average time required to complete the form. For each question on the surveys, the percentage of individuals who responded "unable toassess," along with the mean and standard deviation, was computed to determine the viability of the items and the score profiles. Items in which more than $20 \%$ of responders selected "unable-to-assess" may be in need of revision or deletion according to past findings (Violato et al. 2008).

We used exploratory factor analysis to determine which items on each survey belonged together (i.e., becoming a factor or scale). In this study, using individual-physician data as the unit of analysis for the survey, the items were inter-correlated using Pearson product moment correlations. The correlation matrix was then decomposed into principal components, and these were subsequently rotated to the normalized varimax criterion. Items were considered to be part of a factor if their primary loading was on that factor. The number of factors to be extracted was based on the Kaiser Rule (i.e., eigenvalues >1.0) (Violato and Saberton 2006).

The factors or scales established through exploratory factor analysis were used to establish the key domains (e.g., Communication skills) for improvement, whereas the items within each factor provided more precise information about specific behaviors (e.g., RCSI Bahrain helped me to develop good oral and written communication skills). This analysis made it possible to determine whether the instrument items were aligned into the appropriate constructs (factors) as intended. Each item was assigned to the factor on which they loaded with at least a loading factor of 0.40. If an item loaded in more than one factor (cross-loading) the item was assigned to where it loaded the highest factor (Violato and Saberton 2006). The results of the factor analysis are presented in Table 1.

Instrument reliability (stability) was assessed. Internal consistency reliability was examined by calculating the Cronbach's coefficient for the total scales and for each factor. This calculation provided an assessment of the overall internal consistency for each instrument as well as for each factor within the instruments (Lockyer et al. 2009).

\section{Ethical approval}

The research was approved by the research ethics committee at the RCSI-MUB. Written consent was obtained from the graduates. This study was conducted from March 2014 to July 2014.

\section{Results}

Out of 599 graduates, 153 responded to the graduate survey. The response rate of the graduate survey was
$26 \%$, including $67 \%$ females (n: 102), $29 \%$ males (n: 44 ), and $5 \%$ (n: 7) students who did not indicate their gender. These responses corresponding to the proportion of females in the university since female are presenting $60 \%$ of the total number of graduates. There was a steady increase in response rates with each graduating class. There were a disproportionately higher number of respondents from more recent graduating years, representative of larger cohort sizes. This was also the case due to the ease of access to more recent graduates relative to alumni who graduated a few years prior to this study.

The majority of respondents (83) were working in Bahrain at the time of survey administration (54\%), followed by 11 students in the USA (7\%), 10 students in Canada (7\%), 7 in the United Arab Emirates (5\%), 6 in Saudi Arabia (4\%), 4 in Malta (3\%), and 3 in the UK (2\%); the total number of countries where graduates were working was 14. Other countries represented include Sweden, Qatar, Nigeria, Mali, Kuwait, Germany, and Afghanistan. 17 respondents did not answer this question, leading to $11 \%$ of unaccounted for results.

Of the graduates who responded to the questionnaire, the majority came from Bahrain, representing $53 \%$ (81 students) of respondents. The next highest proportions of students came from Canada (12\%) and the USA (5\%). Graduates represented a diverse array of nationalities, including Venezuela, Sri Lanka, Netherlands, Ghana, Germany, Brazil, and more.

From a satisfaction point view the mean rate of satisfaction ranged from 3.1 cross the item (Q11: The career guidance offered at RCSI Bahrain helped me gain the right type of experiences for my chosen career path) to 4.33 cross the item (Q32: RCSI Bahrain helped me to develop my skills to communicate effectively with patients and staff. Most of the results showed strongly agree with the level of readiness and satisfaction.

The highest rated aspect of the program was in response to the statement "I can establish and maintain constructive working relationships with colleagues" This item received a score of 4.42 out of a total of 5 (standard deviation \pm 0.67 ). The lowest scoring item was "The career guidance offered at RCSI Bahrain helped me gain the right types of experiences for my chosen career path," which scored a 3.10 (standard deviation \pm 1.41 ).

Reliability analysis found high internal consistency for the total scale over the whole instrument items with a (Cronbach's $\alpha$ of 0.97). The reliability analysis across the five factors was measured and it showed a high reliability (Cronbach's coefficients 0.94, 0.92, 0.92, 0.80, 0.82) across the main five domains: future performance, career development, skills development, graduates as collaborator and communication skills respectively. 
Table 1 Descriptive statistics, item analysis and factor analysis

\begin{tabular}{|c|c|c|c|c|c|c|c|}
\hline Question & Mean & SD & $\begin{array}{l}\text { Future } \\
\text { performance }\end{array}$ & $\begin{array}{l}\text { Career } \\
\text { development }\end{array}$ & $\begin{array}{l}\text { Skills } \\
\text { development }\end{array}$ & $\begin{array}{l}\text { Graduates } \\
\text { as collaborator }\end{array}$ & $\begin{array}{l}\text { Communication } \\
\text { skills }\end{array}$ \\
\hline $\begin{array}{l}\text { Q1 My programme pre- } \\
\text { pared me for lifelong } \\
\text { learning }\end{array}$ & 4.10 & 0.87 & 0.540 & & & & \\
\hline $\begin{array}{l}\text { Q2 I am able to use } \\
\text { reflection to enhance } \\
\text { my professional devel- } \\
\text { opment }\end{array}$ & 4.10 & 0.73 & & & & 0.611 & \\
\hline $\begin{array}{l}\text { Q3 I am able to manage } \\
\text { my time effectively }\end{array}$ & 4.15 & 0.78 & & & 0.493 & & \\
\hline $\begin{array}{l}\text { Q4 I understand the role } \\
\text { of the health care pro- } \\
\text { fessionals in the team I } \\
\text { work with }\end{array}$ & 4.31 & 0.78 & & & 0.473 & & \\
\hline $\begin{array}{l}\text { Q5 I have achieved my } \\
\text { professional goals at } \\
\text { this stage in my career }\end{array}$ & 3.50 & 1.21 & & 0.704 & & & \\
\hline $\begin{array}{l}\text { Q6 My programme of } \\
\text { study enhanced my } \\
\text { chances of employ- } \\
\text { ment }\end{array}$ & 3.70 & 1.18 & & & 0.537 & & \\
\hline $\begin{array}{l}\text { Q7 I feel prepared to } \\
\text { pursue postgraduate } \\
\text { study }\end{array}$ & 4.03 & 0.97 & & & 0.642 & & \\
\hline $\begin{array}{l}\text { Q8 My programme of } \\
\text { study was relevant to } \\
\text { the type of employ- } \\
\text { ment I pursued }\end{array}$ & 4.11 & 0.81 & & & & 0.435 & \\
\hline $\begin{array}{l}\text { Q9 My chosen career has } \\
\text { met my expectations }\end{array}$ & 3.75 & 1.20 & & 0.615 & & & \\
\hline $\begin{array}{l}\text { Q10 Career development } \\
\text { was an integral part of } \\
\text { my programme at RCSI } \\
\text { Bahrain }\end{array}$ & 3.25 & 1.36 & & 0.611 & & & \\
\hline $\begin{array}{l}\text { Q11 The career guidance } \\
\text { offered at RCSI Bahrain } \\
\text { helped me gain the } \\
\text { right type of experi- } \\
\text { ences for my chosen } \\
\text { career path }\end{array}$ & 3.10 & 1.41 & & 0.720 & & & \\
\hline $\begin{array}{l}\text { Q12 I have engaged in } \\
\text { continuous profes- } \\
\text { sional development } \\
\text { since my graduation }\end{array}$ & 3.99 & 0.88 & & & & 0.490 & \\
\hline $\begin{array}{l}\text { Q13 My programme } \\
\text { helped me develop my } \\
\text { leadership skills }\end{array}$ & 4.00 & 0.97 & 0.615 & & & & \\
\hline $\begin{array}{l}\text { Q14 1My subject knowl- } \\
\text { edge and understand- } \\
\text { ing was sufficient for } \\
\text { employment }\end{array}$ & 4.13 & 0.82 & & & 0.795 & & \\
\hline $\begin{array}{l}\text { Q15 The curriculum was } \\
\text { up to date and relevant } \\
\text { to practice }\end{array}$ & 4.16 & 0.88 & & & 0.653 & & \\
\hline $\begin{array}{l}\text { Q16 I am familiar with } \\
\text { the RCSI Bahrain } \\
\text { graduate profile for my } \\
\text { profession }\end{array}$ & 3.63 & 1.14 & & 0.623 & & & \\
\hline
\end{tabular}


Table 1 continued

\begin{tabular}{|c|c|c|c|c|c|c|c|}
\hline Question & Mean & SD & $\begin{array}{l}\text { Future } \\
\text { performance }\end{array}$ & $\begin{array}{l}\text { Career } \\
\text { development }\end{array}$ & $\begin{array}{l}\text { Skills } \\
\text { development }\end{array}$ & $\begin{array}{l}\text { Graduates } \\
\text { as collaborator }\end{array}$ & $\begin{array}{l}\text { Communication } \\
\text { skills }\end{array}$ \\
\hline $\begin{array}{l}\text { Q17 My programme } \\
\text { prepared me for } \\
\text { research, scholarship } \\
\text { and enquiry }\end{array}$ & 3.53 & 1.32 & & 0.818 & & & \\
\hline $\begin{array}{l}\text { Q18 I am able to } \\
\text { incorporate relevant } \\
\text { research findings into } \\
\text { healthcare practice }\end{array}$ & 4.01 & 0.85 & & 0.554 & & & \\
\hline $\begin{array}{l}\text { Q19 The VLE was } \\
\text { essential in support- } \\
\text { ing the development } \\
\text { of my knowledge and } \\
\text { understanding }\end{array}$ & 4.23 & 0.82 & 0.581 & & & & \\
\hline $\begin{array}{l}\text { Q20 The time I had to } \\
\text { practice subject spe- } \\
\text { cific skills was sufficient }\end{array}$ & 3.69 & 0.91 & & & 0.608 & & \\
\hline $\begin{array}{l}\text { Q21 Professionalism was } \\
\text { an important topic area } \\
\text { in my programme of } \\
\text { study }\end{array}$ & 4.30 & 0.80 & 0.589 & & & & \\
\hline $\begin{array}{l}\text { Q22 My problem solving } \\
\text { skills were developed } \\
\text { during my programme }\end{array}$ & 4.12 & 0.82 & 0.630 & & & & \\
\hline $\begin{array}{l}\text { Q23 My programme } \\
\text { helped me develop my } \\
\text { decision making skills }\end{array}$ & 4.05 & 0.91 & 0.726 & & & & \\
\hline $\begin{array}{l}\text { Q24 The clinical practice } \\
\text { in my programme was } \\
\text { sufficient for me to } \\
\text { enter my profession }\end{array}$ & 3.87 & 1.11 & & & 0.656 & & \\
\hline $\begin{array}{l}\text { Q25 I am able to contrib- } \\
\text { ute to effective multi- } \\
\text { disciplinary teamwork }\end{array}$ & 4.36 & 0.65 & & & & 0.656 & \\
\hline $\begin{array}{l}\text { Q26 I can establish and } \\
\text { maintain constructive } \\
\text { working relationships } \\
\text { with colleagues }\end{array}$ & 4.42 & 0.67 & & & & 0.668 & \\
\hline $\begin{array}{l}\text { Q27 My clinical experi- } \\
\text { ence enabled me to } \\
\text { make career choices }\end{array}$ & 3.95 & 1.02 & & 0.560 & & & \\
\hline $\begin{array}{l}\text { Q28 My understanding } \\
\text { of cultural diversity } \\
\text { in health care was } \\
\text { enhanced during my } \\
\text { time at RCSI Bahrain }\end{array}$ & 4.23 & 0.84 & 0.528 & & & & \\
\hline $\begin{array}{l}\text { Q29 I understand health } \\
\text { and social care policies } \\
\text { on National and Inter- } \\
\text { national level }\end{array}$ & 3.87 & 0.93 & 0.501 & & & & \\
\hline $\begin{array}{l}\text { Q30 I am able to speak } \\
\text { more than one lan- } \\
\text { guage }\end{array}$ & 4.31 & 0.78 & & & & 0.754 & \\
\hline $\begin{array}{l}\text { Q31 I was able to } \\
\text { develop my language } \\
\text { skills while at RCSI } \\
\text { Bahrain }\end{array}$ & 4.10 & 1.05 & & & & & 0.633 \\
\hline
\end{tabular}


Table 1 continued

\begin{tabular}{|c|c|c|c|c|c|c|c|}
\hline Question & Mean & SD & $\begin{array}{l}\text { Future } \\
\text { performance }\end{array}$ & $\begin{array}{l}\text { Career } \\
\text { development }\end{array}$ & $\begin{array}{l}\text { Skills } \\
\text { development }\end{array}$ & $\begin{array}{l}\text { Graduates } \\
\text { as collaborator }\end{array}$ & $\begin{array}{l}\text { Communication } \\
\text { skills }\end{array}$ \\
\hline $\begin{array}{l}\text { Q32 RCSI Bahrain helped } \\
\text { me to develop my skills } \\
\text { to communicate effec- } \\
\text { tively with patients } \\
\text { and staff }\end{array}$ & 4.33 & 0.84 & & & 0.658 & & \\
\hline $\begin{array}{l}\text { Q33 RCSI Bahrain helped } \\
\text { me to develop good } \\
\text { oral and written com- } \\
\text { munication skills }\end{array}$ & 4.27 & 0.79 & & & & & 0.560 \\
\hline $\begin{array}{l}\text { Q34 RCSI Bahrain helped } \\
\text { me to develop skills } \\
\text { to be adaptable and } \\
\text { flexible in my approach } \\
\text { to work }\end{array}$ & 4.03 & 0.97 & 0.630 & & & & \\
\hline $\begin{array}{l}\text { Q35 RCSI Bahrain helped } \\
\text { me to develop infor- } \\
\text { mation technology } \\
\text { skills that enable me to } \\
\text { use in my practice }\end{array}$ & 3.87 & 1.10 & & & & & 0.636 \\
\hline $\begin{array}{l}\text { Q36 RCSI Bahrain helped } \\
\text { me to develop my } \\
\text { organizational skills }\end{array}$ & 4.02 & 0.92 & 0.739 & & & & \\
\hline Q37 I am self motivated & 4.41 & 0.73 & & & & 0.716 & \\
\hline $\begin{array}{l}\text { Q38 RCSI Bahrain encour- } \\
\text { aged independence in } \\
\text { teaching and learning }\end{array}$ & 4.14 & 0.90 & & 0.554 & & & \\
\hline $\begin{array}{l}\text { Q39 RCSI Bahrain } \\
\text { supported me in } \\
\text { developing confidence } \\
\text { in practice }\end{array}$ & 4.16 & 0.93 & & & 0.549 & & \\
\hline $\begin{array}{l}\text { Q40 My interpersonal } \\
\text { skills were developed } \\
\text { at RCSI Bahrain }\end{array}$ & 4.07 & 0.91 & 0.720 & & & & \\
\hline $\begin{array}{l}\text { Q41 I was encouraged to } \\
\text { be part of wider com- } \\
\text { munity engagement } \\
\text { whilst at RCSI Bahrain }\end{array}$ & 3.79 & 1.08 & 0.567 & & & & \\
\hline
\end{tabular}

The whole instrument was found to be suitable for factor analysis (KMO = 0.853; Bartlett test significant, $\mathrm{p}<0.00)$. Factor analysis showed that the data on the questionnaire decomposed into five factors, which accounted for $72.3 \%$ of the total variance: future performance, career development, skills development, graduates as collaborator, and communication skills. The factors or scales established through exploratory factor analysis were used to establish the key domains (e.g., Future performance) for improvement, whereas the items within each factor provided more precise information about specific domain (e.g., My programme prepared me for lifelong learning, My programme helped me develop my leadership skills, etc.). This analysis made it possible to determine whether the instrument items were aligned into the appropriate constructs (factors) as intended (Table 2).
Table 2 Descriptive statistics for different scales

\begin{tabular}{lccc}
\hline Scale & No of items & Mean & SD \\
\hline Future performance & 12 & 3.52 & 1.35 \\
Career development & 9 & 3.65 & 0.33 \\
Skill development & 10 & 4.05 & 0.22 \\
Graduates as collaborator & 7 & 4.24 & 0.17 \\
Communication skill & 3 & 4.08 & 0.20
\end{tabular}

Data were expressed as mean and SD

\section{Discussion}

This study served to examine the satisfaction of RCSI Bahrain medical graduates, both with the program itself and with their own ability to translate what they had learned into application in real world practice. 


\section{Feasibility}

Despite low response rates, participants responded to nearly all items on the questionnaire. There were no questions that exceeded $20 \%$ of the response "unable to assess" by the respondents, which indicates the feasibility of the survey. The data collected in this study allowed us to effectively and objectively evaluate the medical program offered by RCSI Bahrain. Medical student graduates are unique in that they are considered to be both novices and expertsnovices in the sense that they are new to the clinical professional working world, yet experts in studying and learning relative to other students in non-medicine fields (Garner et al. 2014). This makes their feedback exceptionally valuable as their opinions should and will shape the curriculum for future students. The practice of using student feedback to improve on educational programs is one that dates back for nearly 50 years (Berk 2009). It has been found that student feedback is traditionally the primary source of evaluating faculty performance in universities across the United States (Brinkman et al. 2015).

\section{Psychometrics}

It is important however, to consider that past studies have found that the self-reported confidence of medical students does not necessarily translate into higher competence in certain skills. A study conducted in Amsterdam found that students' self-reported confidence in transcribing was weakly correlated with their actual competence in this key medical skill (Brinkman et al. 2015). This suggests that medical students may have difficulty in accurately self-evaluating their own skills and competencies (Lai and Teng 2011). As such, evaluations such as the medical graduate questionnaire should be taken in tandem with multisource evaluations that include assessment from sources such as fellow faculty members. (Berk 2009) suggests that feedback of medical programs should consider several evaluations including student, peer, outside experts, alumni, and administrators (Berk 2005).

\section{Learner satisfaction}

This study found that student graduates from RCSI felt a strong sense of both satisfaction with their experience in the medical school, as well as a feeling of readiness to enter in the working world upon graduating. Although the word satisfaction was not used in the survey, it is used as a conclusion for the domains that were measured by the survey. If the graduates felt post-graduation that he/ she had developed in different aspects such as future performance, career development, skills development and he/she ready as communicator and collaborator, this will subsequently lead to increased satisfaction levels since graduates master all the competencies required as students at the university. These findings may be limited due to the relatively small sample size due to low response rate, indicating possible respondent bias.

The information produced in this study will be fed back to university administrators such that the program may be adjusted as per student responses. Aspects of the program that resulted in low responses will be reviewed for their improvements for future cohorts and those areas that allowed for a strong satisfaction rate will continue to be monitored and emphasized throughout the curriculum.

\section{Limitations}

This study had several limitations due to the relative newness of the RCSI Bahrain program. As such, only 153 students (a response rate of $26 \%$ ) completed the survey, limiting our sample size. The distribution of the questionnaire was done via university email. This may contribute to the low response rates, especially since students might not use their university e-mail on a regular basis after graduation. Additionally, a low response rate with disproportionate responses from more recent graduating classes suggests difficulty in establishing contact with alumni who graduate in previous years, as many may have changed their contact information from the time of graduation to the time of survey. Such a trend suggests a possible respondent bias, such that recent graduates are more likely to participate in such surveys. It is also possible that individuals who have higher satisfaction levels are more willing to participate in such research studies. This suggests limitations with the representativeness of the sample used in this study.

Secondly, while a student-centered evaluation method is an essential part of revising a medical education program, future studies might benefit from employing a $360^{\circ}$ multisource feedback instead.

\section{Authors' contributions}

$\mathrm{KS}$ and AA contributed to the conception and design of the study. KS worked on the data acquisition. AA, contributed on the data analysis and interpretation of the data. KS and AA contributed on the drafting the manuscript. KS and $A A$ gave the final approval of the version to be published. Both authors read and approved the final manuscript.

\section{Author details}

${ }^{1}$ Royal College of Surgeon of Ireland in Bahrain, Building No 2441, Road 2835 Busaiteen 228, Kingdom of Bahrain. ${ }^{2}$ Department of General Surgery, Bahrain Defense Force Hospital, Off Waly Alahed Avenue, P. O. Box - 28743, West Riffa, Kingdom of Bahrain. ${ }^{3}$ Arabian Gulf University, Building 293, Manama 329, Kingdom of Bahrain.

\section{Acknowledgements}

The author would like to thank Richard Arnett and Fadi Ghosen for their help during piloting the survey.

\section{Competing interests}

All authors declare that they have no competing interests.

Received: 2 September 2015 Accepted: 1 March 2016

Published online: 10 March 2016 


\section{References}

Association of American Medical Colleges (2012) Medical School Graduation Questionnaire: 2012 all schools summary report

Berk RA (2005) Survey of 12 strategies to measure teaching effectiveness. Int J Teach Learn Higher Educ 17(1):48-62

Berk RA (2009) Using the $360^{\circ}$ multisource feedback model to evaluate teaching and professionalism. Med Teach 31(12):1073-1080

Brinkman DJ, Tichelaar J, Agtmael MAV (2015) Self-reported confidence in prescribing skills correlates poorly with assessed competence in fourth-year medical students. J Clin Pharmacol 55(7):825-830

Garner MS, Gusberg RJ, Kim AW (2014) The positive effect of immediate feedback on medical student education during the surgical clerkship. J Surg Educ 71(3):391-397

Illing JC, Morrow GM, Kergon CR et al (2013) Perceptions of UK medical graduates' preparedness for practice: a multicentre qualitative study reflecting the importance of learning on the job. BMC Med Educ 13:34
Lai NM, Teng CL (2011) Self-perceived competence correlates poorly with objectively measured competence in evidence based medicine among medical students. BMC Med Educ 11:25

Lambert TW, Surman G, Goldacre MJ (2013) Views of UK-trained medical graduates of 1999-2009 about their first postgraduate year of training: national surveys. BMJ Open 3:e002723

Lockyer J, Violato C, Fidler H, Alakija P (2009) The assessment of pathologists/ laboratory medicine physicians through a multisource feedback tool. Arch Pathol Lab Med 133(8):1301-1308

Mavis B, Sousa A, Lipscomb W et al (2014) Learning about medical student mistreatment from responses to the medical school graduation questionnaire. Acad Med 89(5):705-711

Violato C, Saberton S (2006) Assessing medical radiation technologists in practice: a multi-source feedback system for quality assurance. Can J Med Radiat Technol 37(2):10-17

Violato C, Lockyer JM, Fidler H (2008) Assessment of psychiatrists in practice through multisource feedback. Can J Psychiatry 53(8):525-533

\section{Submit your manuscript to a SpringerOpen ${ }^{\circ}$ journal and benefit from:}

- Convenient online submission

- Rigorous peer review

- Immediate publication on acceptance

- Open access: articles freely available online

- High visibility within the field

- Retaining the copyright to your article

Submit your next manuscript at $>$ springeropen.com 